Journal of Clinical Investigation

Vol. 43, No. 4, 1964

\title{
Inhibition by RNA of the Transfer Reaction Following Homograft Sensitization *
}

\author{
John A. Mannick $\dagger$ \\ (From the Strauss Surgical Research Laboratories and the Department of Surgery, Medical \\ College of Virginia, Richmond, Va.)
}

The ability of ribonucleic acid (RNA) extracted from viruses to alter the subsequent metabolic behavior of mammalian cells has now been clearly established by such virologists as Alexander, Koch, Mountain, and Van Damme (1) and Ellem and Colter (2). The effects of nonviral RNA on mammalian cells have been less thoroughly investigated. However, experiments of DeCarvalho and Rand (3) and Niu, Cordova, and $\mathrm{Niu}$ (4) have indicated that RNA extracted from normal tissue may inhibit the malignant potential and alter the metabolism of certain rodent tumors. Amos and Kearns (5) have recently presented evidence that chicken fibroblasts can be induced to synthesize bacterial protein by exposure to RNA extracted from Escherichia coli. Prior studies in this laboratory $(6,7)$ have shown that previously unstimulated rabbit lymph nodes cells may be transformed to a state resembling transplantation immunity by incubation with RNA extracted from the lymph nodes of a rabbit immunized by skin homografts. More recently, Fishman and Adler (8) have shown that lymph node cells, which have been incubated with RNA extracted from macrophages previously exposed to bacteriophage antigen, will subsequently form antibody against this antigen. Thus there is evidence that antibody synthesis may be induced by appropriate foreign RNA.

Conversely, the investigations reported here were undertaken to determine whether or not lymph node cells from the recipient of skin homografts could be prevented from manifesting transplantation immunity by incubation with lymph node RNA from the homograft donor. A further

\footnotetext{
* Submitted for publication September 25, 1963; accepted December 19, 1963.

Supported in part by U. S. Public Health Service research grants CA- 05725 and AM-07495 and by Atomic Energy Commission grant AT-(40-1)-2459.

$\dagger$ Markle Scholar in Medical Sciences.
}

purpose of this work was the characterization of the RNA preparation extracted from rabbit lymph nodes and a study of its incorporation by lymph node cells during incubation in vitro.

The assay of transplantation immunity selected for use in these, as in our previous experiments, was the transfer reaction initially described by Brent, Brown, and Medawar (9) in guinea pigs and more recently characterized by Dvorak and Waksman (10) and Jankovic and Dvorak (11) in rabbits. The transfer reaction was selected because of its simplicity and marked sensitivity, the degree of which is indicated by the fact that consistently positive results may be obtained with as few as 4 to 10 million cells $(6,7)$.

\section{Methods}

Purposely outbred, adult, white New Zealand rabbits of both sexes, weighing 2 to $4 \mathrm{~kg}$, obtained from a single breeder were used as experimental animals. The rabbits were caged individually in an air-conditioned animal room and were fed a diet of water and Purina rabbit chow. Skin grafting and excision of lymph nodes and spleens were carried out by sterile surgical technique and, unless the donor was to be sacrificed, were performed under pentobarbital anesthesia (25 $\mathrm{mg}$ per $\mathrm{kg}$ ) supplemented with local procaine infiltration. Skin grafts were all full-thickness grafts approximately $1.5 \mathrm{~cm}$ square. Grafts were excised from the ears of donor rabbits and sutured in place in beds prepared on the lower hind legs of the recipient rabbits in all instances. Popliteal lymph nodes to be used for RNA extraction were ordinarily stimulated by injection of $20 \mathrm{mg}$ of bovine serum albumin (BSA) 1 in Freund's complete adjuvant into the foot pads 5 to 6 days before excision of the nodes.

RNA was prepared by the modification by Colter and Brown (12) of the method of Gierer and Schramm (13). Freshly excised tissue (ordinarily lymph nodes) was carefully cleaned of attached fat and fibrous tissue and was then immediately frozen in a mortar suspended in a bath of dry ice and alcohol and ground to a powder with a pestle. The frozen, powdered tissue was sus-

${ }^{1}$ Nutritional Biochemicals, Cleveland, Ohio. 
pended in 3 vol of $0.14 \mathrm{M} \mathrm{NaCl}$ containing $0.01 \mathrm{M}$ sodium citrate. This and all subsequent steps of the RNA extraction were carried out in a cold room at $5^{\circ} \mathrm{C}$. The resultant suspension was homogenized for 10 minutes at $30,000 \mathrm{rpm}$ in a Virtis homogenizer. The homogenate was then spun in a refrigerated centrifuge at $1,200 \times g$ to remove all gross cellular debris. The precipitate was discarded, and the supernatant fluid was extracted for 15 minutes with an equal volume of water-saturated phenol, redistilled before use. The material was again centrifuged at $3,000 \times g$ for 15 minutes. The heavy phenol and cloudy interface were discarded, and the clear supernatant fluid was retained. The phenol extraction was repeated 3 to 5 times, and the last supernatant fluid was then extracted 8 times with freshly distilled ether to remove the phenol. Ether was removed as a final step by bubbling nitrogen through the solution.

The presence of DNA was determined by the diphenylamine test of Dische (14). The presence of protein was determined by the microbiuret test described by Zamenhof (15). Nitrogen was determined by the micro-Kjeldahl technique as described by $\mathrm{Ma}$ and Zuazaga (16) and phosphorus by the method of Hawk, Oser, and Summerson (17). The absorption spectrum of the preparation was measured in a Beckman model DU spectrophotometer with a hydrogen lamp. The concentration of RNA present in the preparation was determined by the optical density at $260 \mathrm{~m} \mu$ in the spectrophotometer (18) and by the orcinol test as described by Mejbaum (19). Commercial yeast $\mathrm{RNA}^{2}$ was used as the standard. Ultracentrifugal analyses were performed in a Spinco model $\mathrm{E}$ analytical ultracentrifuge with a schlieren optical system.

Tritium-labeled RNA used in some experiments was prepared by injecting donor rabbits with a total of 1,000 $\mu \mathrm{c}$ of tritiated uridine $(1.3 \mathrm{c} \text { per mmole })^{2}$ administered in three divided doses at 4-hour intervals. Twenty-four hours after the first injection the donor rabbit was sacrificed, and the RNA was extracted from the lymph nodes as usual.

Lymph node cell suspensions were prepared by teasing the excised nodes apart in cool Eagle Hela medium ${ }^{3}$ containing penicillin, $100 \mathrm{U}$ per $\mathrm{ml}$, and streptomycin, 100 $\mu \mathrm{g}$ per $\mathrm{ml}$. Twenty per cent commercial rabbit serum, ${ }^{3}$ or in some experiments, polyvinylpyrolidone (PVP), $10 \%$ by weight, was added to stabilize the cells. The cell suspension was passed through a stainless steel wire screen of $307-\mu$ pore size, and a cell count was performed with a standard clinical hemocytometer. Cell viability was determined by dye exclusion using $1 \%$ eosin-Y. Before incubation with RNA the cells were collected by centrifugation at $500 \times g$ and were suspended in the RNA preparation. The RNA preparation was always used immediately after extraction; it was made $0.7 \mathrm{M}$ with respect to sucrose, and the $\mathrm{pH}$ was adjusted to 7.0 to 7.6 before incubation with the cells. Control samples of cells were incubated in citrate-buffered saline made $0.7 \mathrm{M}$

2 Schwartz Bioresearch, Inc., Orangeburg, N. Y.

${ }^{3}$ Difco Laboratories, Detroit, Mich. with respect to sucrose and containing no RNA. Incubation was carried out for 15 minutes in a water bath at $37^{\circ} \mathrm{C}$ with frequent agitation of the cell suspension. After incubation the cell suspensions were centrifuged $(500 \times g)$, washed, and resuspended in Eagle Hela medium containing $20 \%$ rabbit serum. Cell counts and cell viability determinations were repeated at this point. Cell viability was ordinarily greater than $80 \%$ and did not vary significantly in RNA-treated and control samples of cells. Any experiment in which the final cell viability of any sample was less than $70 \%$ was discarded.

Cell suspensions were injected intradermally in volumes of 1.0 to $2.0 \mathrm{ml}$ at one or two sites in a circumscribed area of skin on one side of the back well out of reach of the rabbit's feet and teeth. Positive reactions when they occurred appeared as areas of induration with surrounding erythema at the injection sites. The reactions ordinarily became manifest at 12 to 24 hours, reached a maximum at 48 to 72 hours, and then gradually disappeared over the next 2 to 4 days. The skin reactions were graded on a scale from 0 to $5+$ depending upon the diameter of the area of induration produced. The amount of accompanying erythema varied considerably from experiment to experiment and was disregarded in scoring the reactions. An area of induration less than $5 \mathrm{~mm}$ in diameter was scored as a 1 + reaction. This was not considered significant. A $2+$ reaction (the smallest reaction considered significant) was an area of induration greater than $5 \mathrm{~mm}$ and less than 1.0 $\mathrm{cm}$ in diameter. A $3+$ reaction was an area of induration greater than $1.0 \mathrm{~cm}$ but less than $1.5 \mathrm{~cm}$ in diameter. A $4+$ reaction was an area of induration greater than $1.5 \mathrm{~cm}$ in diameter, and a $5+$ reaction was a $4+$ reaction that progressed to necrosis of the overlying skin.

\section{Results}

\section{Characterization of $R N A$ preparation}

Analysis for $D N A$. The diphenylamine test was consistently negative when performed on five successive lymph node RNA preparations.

Analysis for protein. The crude RNA preparations used in these experiments contained from 0.5 to $10 \%$ biuret positive material as determined by the microbiuret test.

Spectrophotometric analysis. The ultraviolet absorption spectrum of the crude RNA preparation has been described previously (7) and is characteristic of a nucleic acid with the absorption maximum at or near $260 \mathrm{~m} \mu$. The $\mathrm{E}^{1 \%} 1 \mathrm{~cm}$ $260 \mathrm{~m} \mu=$ approximately 210 . The hyperchromatic effect of hydrolysis by $\mathrm{NaOH}$ was approximately $30 \%$. The hyperchromatic effect of incubation for 30 minutes with ribonuclease ${ }^{4}$ (15

\footnotetext{
${ }^{4}$ Crystalline bovine pancreatic ribonuclease, Worthington Biochemicals Corp., Freehold, N. J.
} 

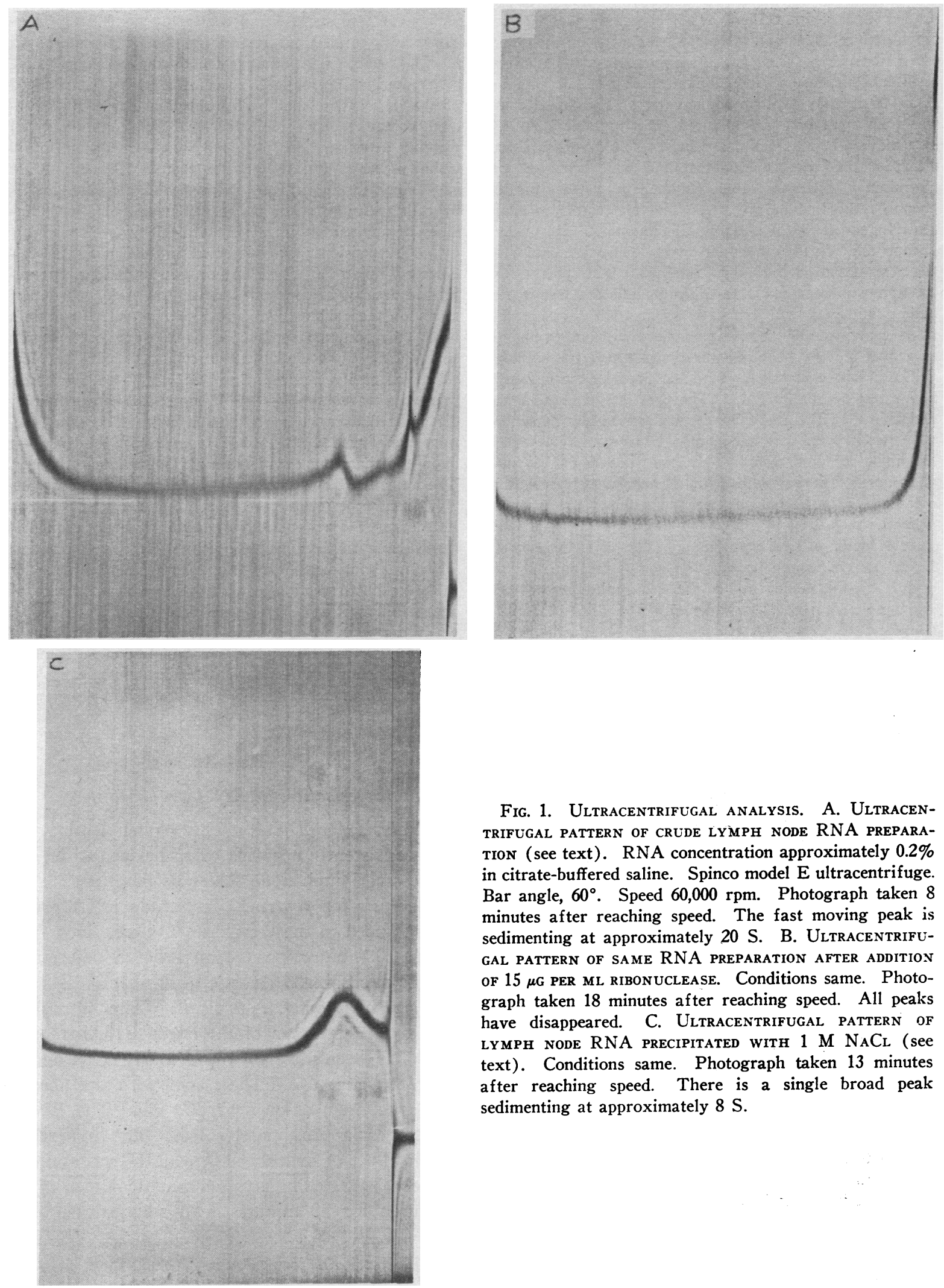

Fig. 1. Ultracentrifugal analysis. A. UltracenTRIFUGAL PATTERN OF CRUDE LYMPH NODE RNA PREPARATION (see text). RNA concentration approximately $0.2 \%$ in citrate-buffered saline. Spinco model $\mathrm{E}$ ultracentrifuge. Bar angle, $60^{\circ}$. Speed $60,000 \mathrm{rpm}$. Photograph taken 8 minutes after reaching speed. The fast moving peak is sedimenting at approximately $20 \mathrm{~S}$. B. UltracentrifuGAL PATTERN OF SAME RNA PREPARATION AFTER ADDITION of $15 \mu \mathrm{G}$ PER ML RIBOnUClease. Conditions same. Photograph taken 18 minutes after reaching speed. All peaks have disappeared. C. Ultracentrifugal PATtern OF LYMPH NODE RNA PRECIPITATED WITH $1 \mathrm{M} \mathrm{NACl}_{\mathrm{L}}$ (see text). Conditions same. Photograph taken 13 minutes after reaching speed. There is a single broad peak sedimenting at approximately $8 \mathrm{~S}$. 
TABLE I

Measurement of $R N A$ concentration

\begin{tabular}{ccc}
\hline & \multicolumn{2}{c}{$\begin{array}{c}\text { Comparative concen- } \\
\text { tration ot RN. }\end{array}$} \\
\cline { 2 - 3 } $\begin{array}{c}\text { Sample } \\
\text { no. }\end{array}$ & $\begin{array}{l}\text { Optical } \\
\text { density } \\
\text { method }\end{array}$ & $\begin{array}{c}\text { Orcinol } \\
\text { method }\end{array}$ \\
\hline & $\mu g / m l$ & $\mu g / m l$ \\
8 & 65 & 80 \\
13 & 90 & 130 \\
14 & 85 & 100 \\
15 & 180 & 220 \\
20 & 20 & 25 \\
26 & 15 & 15 \\
27 & 10 & 10 \\
28 & 215 & 200 \\
30 & 250 & 250
\end{tabular}

* Concentration of R.YA in the same sample of rabbit lymph node RNA as measured by optical density at 260 $\mathrm{m} \mu$ and by orcinol method.

$\mu \mathrm{g}$ per $\mathrm{ml}$ ) ranged from 12 to $18 \%$ in five experiments.

Orcinol test. The quantitative orcinol determination was found to agree with the RNA concentration as determined by the optical density (Table I).

Nitrogen and phosphorus. For chemical analysis the crude RNA preparation was dialyzed against distilled water for 6 hours with constant agitation of the dialysis bag and frequent changes of water. After dialysis RNA was precipitated out of the remaining solution in the cold by the addition of $1 \frac{1}{2} \mathrm{vol}$ of absolute ethanol. The precipitated RNA was collected by centrifugation at $1,200 \times g$ for 20 minutes. The supernatant fluid was discarded, and the RNA was washed 3 times with a $3: 1$ solution of ethanol and water. After washing the RNA precipitate was redissolved in a small amount of distilled water for analysis. The final product contained no biuret positive material. The RNA contained $8.7 \%$ phosphorus and $14.9 \%$ nitrogen. The $\mathrm{N}: \mathrm{P}$ ratio was therefore 1.7. The $\epsilon \mathrm{P}$ or optical density per mole of phosphorus was approximately 7,800 .

Ultracentrifugal analysis. The ultracentrifugal pattern of the crude RNA preparation used in these experiments is shown in Figure 1A. In each of three separate determinations the material formed at least three peaks sedimenting at approximately $4 \mathrm{~S}, 8 \mathrm{~S}$, and $20 \mathrm{~S}$, respectively. A small $16 \mathrm{~S}$ peak was also seen on two occasions. The effect of the addition of $15 \mu \mathrm{g}$ per $\mathrm{ml}$ of ribonuclease on the ultracentrifugal appearance of the same preparation is shown in Figure 1B; all the peaks have disappeared. An attempt was made to prepare a relatively pure sample of highly polymerized RNA by precipitation in the cold with $1 \mathrm{M} \mathrm{NaCl}$ solution after redissolving alcohol-precipitated RNA prepared as described above. The $1 \mathrm{M} \mathrm{NaCl}$ precipitate was collected by centrifugation and redissolved in distilled water for ultracentrifugal analysis. The appearance of this preparation in the ultracentrifuge is shown in Figure 1C. The material formed a single broad peak at approximately $8 \mathrm{~S}$. This result was interpreted as indicating a not unexpected degradation of the $20 \mathrm{~S}$ material during preparation.

Incorporation of RNA by lymphoid cells. Samples of fresh rabbit lymph node cells were suspended for incubation in solutions containing 100 to $350 \mu \mathrm{g}$ per $\mathrm{ml}$ of tritiated RNA prepared by in vivo injection of tritiated uridine as noted above. Incubation conditions were those described previously. After incubation the cell suspensions were centrifuged, washed with Eagle Hela medium, and finally suspended in a small amount of Eagle Hela medium containing $20 \%$ rabbit serum. The resultant cell suspension was smeared out on clean microscope slides for radioautography. Radioautographs were prepared with Kodak NTB-3 nuclear track emulsion and were stored for 4 weeks. The radioautographs were then developed with Kodak D-19 developer and stained lightly with Wright's stain. The percentage of labeled cells was estimated by counting 500 cells in random fields; a cell that contained more than 3 grains was considered a labeled cell. Labeling appeared to be chiefly cystoplasmic; however, nuclei were also labeled in some cells. A typical radioautograph is shown in Figure 2A.

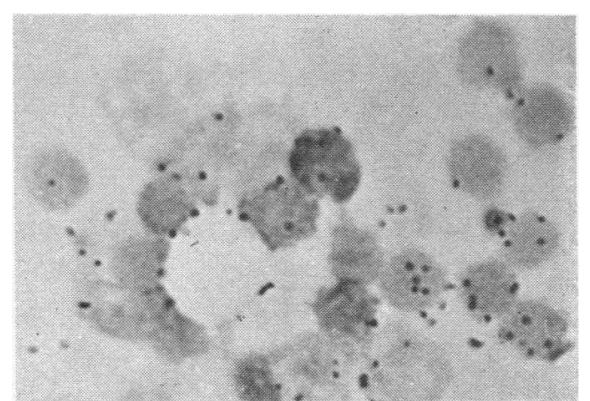

Fig. 2. Uptake of tRitium-LAbeled RNA. Radioautograph of lymph node cell suspension incubated with tritium-labeled RNA (see text). $\times 780$. 
TABLE II

Uptake of tritiated RNA

\begin{tabular}{cccc}
\hline \hline & \multicolumn{3}{c}{$\begin{array}{c}\text { Percentage of labeled } \\
\text { lymphoid cells* }\end{array}$} \\
\cline { 2 - 4 } $\begin{array}{c}\text { Sample } \\
\text { no. }\end{array}$ & $\begin{array}{c}\text { RNA-H } \\
\text { only } \\
\text { control }\end{array}$ & $\begin{array}{c}\text { RNA-H } \\
+ \\
\text { excess } \\
\text { uridine }\end{array}$ & $\begin{array}{c}\text { RNA-H } \\
+ \\
\text { excess } \\
\text { RNA }\end{array}$ \\
\hline 1 & 27 & 29 & $11 \dagger$ \\
2 & 30 & 26 & $13 \dagger$ \\
3 & 31 & 28 & $10 \dagger$
\end{tabular}

* Percentage of labeled cells determined from radioautographs by counting 500 cells in random fields. See text. $\dagger$ Significance of difference from control, $p<0.01$ by the chi-square test.

The percentage of labeled cells was 20,31 , and $33 \%$, respectively, in three experiments.

To determine in what form the tritium label had been incorporated into the cells, the effect of a large excess of unlabeled carrier uridine was studied in an experiment performed in triplicate. Equal aliquots of fresh lymph node cells were incubated simultaneously in equal concentrations of tritium-labeled RNA extracted from the same donor rabbit. A 300-fold excess of carrier uridine was added to the incubation medium containing 1 aliquot of cells. No carrier uridine was added to the other aliquot. Radioautographs were prepared from each aliquot as before. As shown in Table II the excess carrier uridine did not produce a reduction in the percentage of labeled cells. The intensity of cellular labeling also did not appear to be diminished. This result was interpreted as indicating that the tritium label had not entered the cells as free uridine. To determine the effect of an excess of unlabeled carrier RNA on the incorporation of the tritium label, a third, equal aliquot of cells was incubated in tritiated RNA to which a 100-fold excess of rabbit spleen and lymph node RNA prepared from an unlabeled donor was added. As shown in Table II the addition of the excess unlabeled carrier RNA significantly diminished the percentage of labeled cells $(\mathrm{p}<0.01$ by the chi-square test) (20).

To demonstrate the viability of lymph node cells after incubation, aliquots of cells on two occasions were grown in Eagle Hela medium and $20 \%$ rabbit serum on cover slips for 48 hours in vitro after incubation with tritium-labeled RNA. Radioautographs were prepared from these cover slips as before. Tritium-labeled cells were found to have attached themselves to the glass and appeared to be growing satisfactorily. As noted previously, samples of cells tested immediately after incubation have consistently demonstrated more than $80 \%$ viability by dye exclusion technique.

\section{Inhibition of Transfer Reaction}

Effect of donor RNA. The experimental protocol used in these and subsequent experiments is illustrated in Figure 3. Rabbits were studied in pairs. Skin homografts from the donor rabbit were sewn in place on the lower hind legs of the recipient rabbit of each pair. In addition a lymphoid cell suspension from the donor rabbit spleen was injected into the foot pads of the hind feet of the recipient rabbit. After 8 days, at the time of graft rejection, the popliteal lymph nodes draining the homografts and the sites of spleen

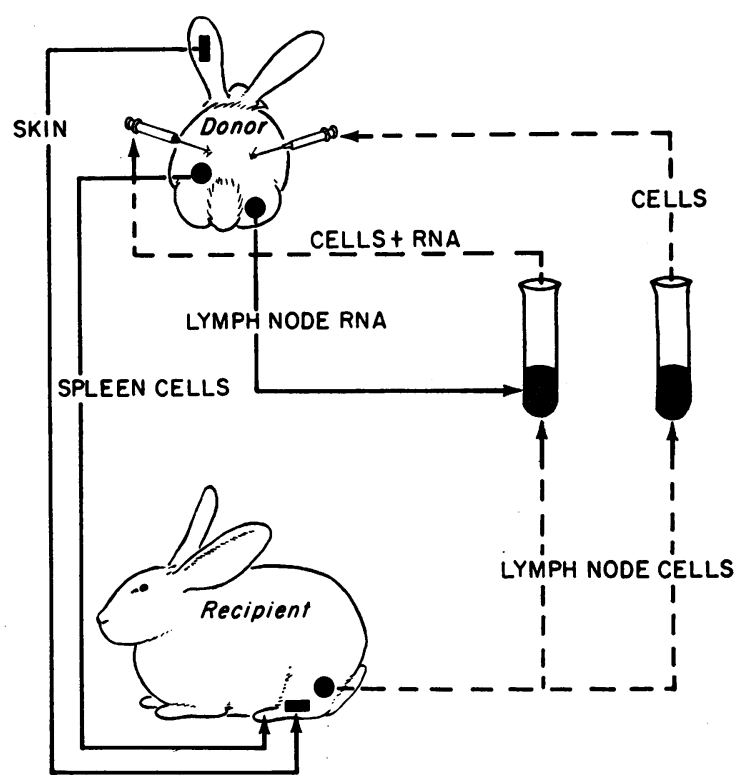

Fig. 3. Experimental PROTOCOL. Diagrammatic illustration of the basic protocol used in transfer reaction experiments. Eight days after sensitization by a skin homograft and an injection of spleen cells from the donor, the popliteal lymph nodes are excised from the recipient. A cell suspension is prepared from these nodes and is divided into equal aliquots. One aliquot is incubated in vitro with RNA extracted from the donor's lymph nodes; the other aliquot is simultaneously incubated in an identical medium containing no RNA (see text). After incubation equal numbers of cells from each aliquot are injected intradermally into opposite sides of the donor's back. 
cell injection were excised from the recipient rabbit. A cell suspension was prepared from these nodes and divided into two equal aliquots. One aliquot was incubated in RNA extracted from the popliteal lymph nodes of the homograft donor. As noted above, the RNA preparation was made $0.7 \mathrm{M}$ with respect to sucrose and the $\mathrm{pH}$ adjusted to neutrality before incubation. As a control the other aliquot of cells was incubated simultaneously in citrate-buffered saline made $0.7 \mathrm{M}$ with respect to sucrose. After incubation both aliquots of cells were collected by centrifugation, washed, and counted. The cell viability was checked, and the two aliquots were injected intradermally into opposite sides of the donor rabbit. The number of cells injected was $8-15 \times 10^{6}$, and care was taken to insure that equal numbers of cells were injected into opposite sides of the donor in each experiment (variation $<8 \times 10^{5}$ cells). The results of this experiment are summarized in Table III. It is apparent that in six of the seven experiments the aliquot of immune recipient cells incubated in sucrose medium alone produced a significant transfer reaction when injected into the donor. It is also clear that the aliquot of immune cells incubated
TABLE III

Transfer reactions, immune cells plus donor RNA

\begin{tabular}{cccl}
\hline \hline $\begin{array}{c}\text { Rabbit } \\
\text { no. }\end{array}$ & $\begin{array}{c}\text { Concen- } \\
\text { tration of } \\
\text { RNA }\end{array}$ & $\begin{array}{c}\text { Right } \\
\text { side } \\
\text { Cells }\end{array}$ & $\begin{array}{c}\text { Left side } \\
\text { Cells } \\
\text { +RNA }\end{array}$ \\
\hline & $\mu \mathrm{g} / \mathrm{ml}$ & & \\
220 & 170 & $4+$ & $2+$ \\
217 & 200 & $5+$ & $2+^{*}$ \\
212 & & $1+$ & $0^{*}$ \\
236 & 500 & $3+$ & 0 \\
1321 & 430 & $3+$ & $0^{*}$ \\
1318 & 360 & $3+$ & 0 \\
1324 & 350 & & 0 \\
\hline
\end{tabular}

* RNA extracted from donor lymph nodes previously stimulated by injection of bovine serum albumin in adjuvant. In remaining experiments RNA was extracted from unstimulated donor lymph nodes.

in donor lymph node RNA failed to produce a significant transfer reaction in five of the seven experiments. This difference is significant statistically by the chi-square test, $\mathrm{p}<0.01$. In two of the experiments the RNA-treated recipient cells did produce a significant transfer reaction which, however, was considerably less intense than that produced by the aliquot of cells incubated in sucrose medium alone. As noted in Table III RNA extracted from lymph nodes stimulated by BSA in adjuvant and RNA extracted

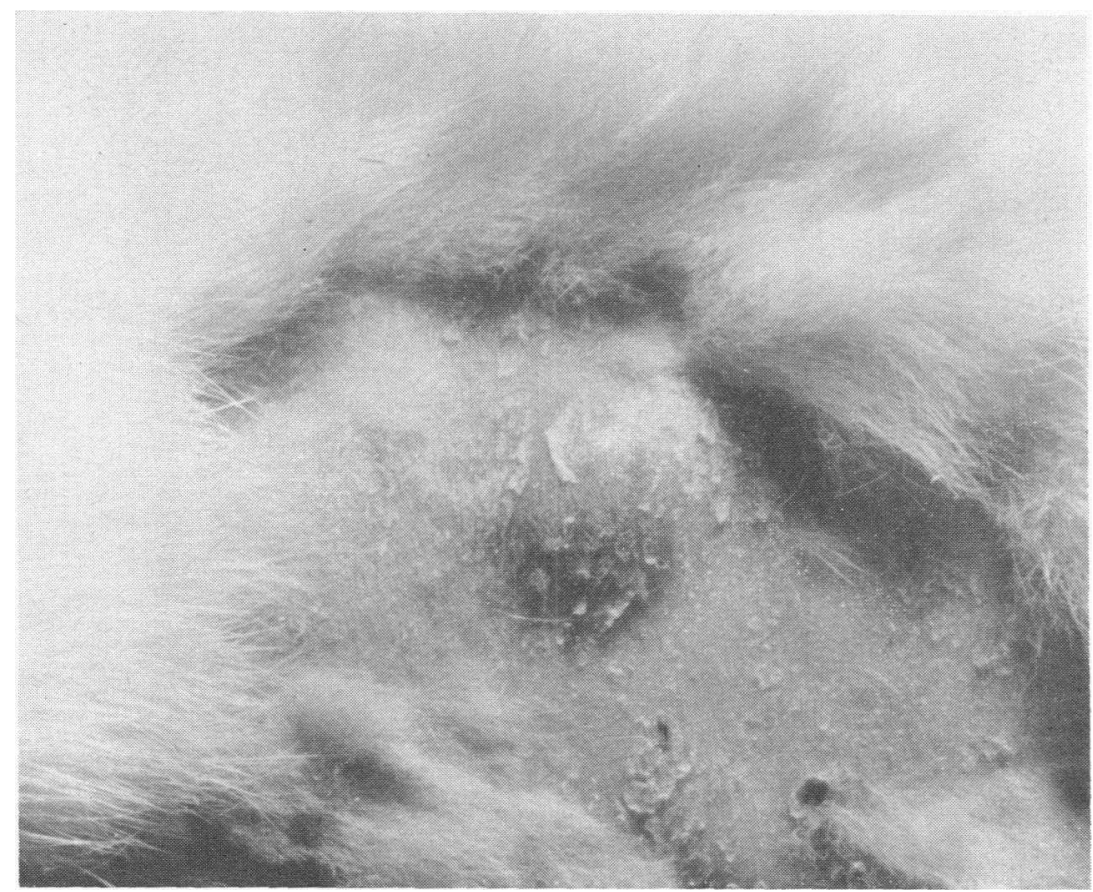

Fig. 4. Typical tRANSFER REACtion. Gross appearance of a $4+$ transfer reaction 72 hours after cell injection. 
TABLE IV

Transfer reactions; immune cells plus donor $R N A-R$ Nase effect

\begin{tabular}{|c|c|c|c|c|}
\hline \multirow[b]{2}{*}{$\begin{array}{l}\text { Rabbit } \\
\text { no. }\end{array}$} & \multirow[b]{2}{*}{$\begin{array}{l}\text { Concen- } \\
\text { tration of } \\
\text { RNA }\end{array}$} & \multicolumn{2}{|c|}{ Right side } & \multirow[b]{2}{*}{$\begin{array}{c}\text { Left side } \\
\text { Cells } \\
\text { +RNA }\end{array}$} \\
\hline & & $\begin{array}{c}\text { Front } \\
\text { Cells } \\
\text { +RNA } \\
+ \text { +RNase }\end{array}$ & $\begin{array}{l}\text { Rear } \\
\text { Cells }\end{array}$ & \\
\hline & $\mu g / m l$ & & & \\
\hline 1116 & 190 & $2+$ & $2+$ & 0 \\
\hline 1120 & 225 & $4+$ & $4+$ & $\mathbf{0}$ \\
\hline 1104 & 170 & $1+$ & \pm & 0 \\
\hline 1077 & 520 & $2+$ & $1+$ & $\mathbf{0}$ \\
\hline 1093 & 400 & $3+$ & $3+$ & $1+$ \\
\hline 1086 & 165 & $1+$ & $1+$ & 0 \\
\hline 1090 & 205 & $1+$ & $2+$ & 0 \\
\hline 1096 & 250 & $1+$ & $2+$ & $\mathbf{0}$ \\
\hline 1084 & 85 & $4+$ & $4+$ & $1+$ \\
\hline 1097 & 365 & $4+$ & $4+$ & $1+$ \\
\hline 1073 & 105 & $3+$ & $5+$ & 0 \\
\hline 1074 & 450 & 0 & 0 & o \\
\hline 1066 & 340 & $2+$ & $1+$ & $\mathbf{0}$ \\
\hline
\end{tabular}

from unstimulated lymph nodes appeared to be equally effective.

A typical transfer reaction is illustrated in Figure 4. The pathology of the transfer reaction, described previously (7), consists of an infiltration of the dermis by histiocytes.

Effect of ribonuclease. To confirm the importance of RNA in the production of the observed results, the RNA preparation extracted from donor rabbit popliteal lymph nodes was divided into two equal aliquots. Both aliquots of RNA were incubated with equal numbers of immune recipient lymph node cells; however, ribonuclease $(15 \mu \mathrm{g}$ per $\mathrm{ml}$ ) was added to one aliquot of RNA at the time of incubation. The other aliquot of RNA was untreated. A third equal sample of immune lymph node cells was simultaneously incubated in sucrose medium containing no RNA. After incubation the three aliquots of cells were washed, counted, and injected in equal numbers intradermally into three separate areas in the skin of the donor rabbit's back. The results are summarized in Table IV. In 8 of the 13 experiments the aliquot of immune cells incubated with ribonuclease-treated RNA produced a transfer reaction comparable in intensity to that produced by the aliquot of immune cells incubated in sucrose medium alone, whereas the aliquot of immune cells incubated with untreated donor RNA failed to produce a significant transfer reaction in any instance. This difference is significant, $\mathrm{p}<$ 0.001 .
Recipient RNA as contrasted with donor RNA. In this group of experiments immune cells from one recipient popliteal lymph node were divided into two equal aliquots. One aliquot was incubated in donor lymph node RNA as before. The other aliquot was incubated in RNA extracted from the opposite recipient popliteal lymph node and was, therefore, presumably reactive RNA as defined in previous reports from this laboratory $(6,7)$. After incubation both aliquots of cells were washed, counted, and injected intradermally into opposite sides of the donor rabbit. The results are summarized in Table V. It is apparent that in 13 of the 15 instances the aliquot of inmune cells incubated with reactive recipient RNA produced a significant transfer reaction in the donor, whereas, the aliquot of immune cells incubated with donor RNA produced a significant transfer reaction in only three instances. Again the difference is significant $(p<0.001)$, and in two of these experiments the reaction produced by the aliquot of cells incubated with donor RNA was less intense than that produced by the aliquot incubated with reactive recipient $\mathrm{RNA}$.

In 8 of the 15 experiments (Table V) the concentration of recipient RNA was greater than the concentration of donor RNA, in 5 experiments the concentration of donor RNA was greater, and in 2 experiments the concentrations were equal. These variations in relative RNA

TABLE V

Transfer reactions; donor R.VA vs. recipient $R N A$

\begin{tabular}{|c|c|c|c|c|}
\hline \multirow[b]{2}{*}{$\begin{array}{c}\text { Rabbit } \\
\text { no. }\end{array}$} & \multicolumn{2}{|c|}{$\begin{array}{l}\text { Right side } \\
\text { Cells +recipi- } \\
\text { ent RNA }\end{array}$} & \multicolumn{2}{|c|}{$\begin{array}{c}\text { Left side } \\
\text { Cells +donor } \\
\text { RNA }\end{array}$} \\
\hline & $\begin{array}{l}\text { Reac- } \\
\text { tion }\end{array}$ & $\begin{array}{l}\text { Concen- } \\
\text { tration } \\
\text { of RNA }\end{array}$ & $\begin{array}{c}\text { Reac- } \\
\text { tion }\end{array}$ & $\begin{array}{l}\text { Concen- } \\
\text { tration } \\
\text { of RNA }\end{array}$ \\
\hline & & $\mu g / m l$ & & $\mu g / m l$ \\
\hline 427 & $4+$ & 205 & $1+$ & 85 \\
\hline 454 & $1+$ & 350 & 0 & 100 \\
\hline 449 & $3+$ & 250 & $3+$ & 200 \\
\hline 439 & $5+$ & 150 & $2+$ & 105 \\
\hline 436 & $4+$ & 75 & $3+$ & 155 \\
\hline 444 & $2+$ & 180 & 0 & 110 \\
\hline 438 & $5+$ & 135 & $1+$ & 235 \\
\hline 365 & 0 & 180 & 0 & 150 \\
\hline 354 & $4+$ & 450 & $\mathbf{0}$ & 270 \\
\hline 367 & $2+$ & 225 & $1+$ & 340 \\
\hline 333 & $4+$ & 90 & $\mathbf{0}$ & 90 \\
\hline 344 & $2+$ & 100 & 0 & 100 \\
\hline 338 & $2+$ & 65 & \pm & 105 \\
\hline 348 & $2+$ & 115 & $1+$ & 300 \\
\hline 368 & $4+$ & 160 & 0 & 130 \\
\hline
\end{tabular}


TABLE VI

Transfer reactions; immune cells plus indifferent $R N A$

\begin{tabular}{cccc}
\hline \hline $\begin{array}{c}\text { Rabbit } \\
\text { no. }\end{array}$ & $\begin{array}{c}\text { Concen- } \\
\text { tration } \\
\text { of RNA }\end{array}$ & $\begin{array}{c}\text { Right side } \\
\text { Cells }\end{array}$ & $\begin{array}{c}\text { Left side } \\
\text { Cells } \\
\text { +RNA }\end{array}$ \\
\hline & $\mu g / m l$ & & \\
1109 & 520 & $1+$ & 0 \\
1115 & 215 & $3+$ & \pm \\
1102 & 215 & $4+$ & 0 \\
1119 & 405 & $3+$ & \pm \\
1112 & 450 & $3+$ & $1+$ \\
1980 & 450 & $3+$ & 0 \\
1975 & 450 & $5+$ & 0 \\
1767 & 360 & $4+$ & $1+$ \\
1172 & 360 & $4+$ & $4+$ \\
1775 & 120 & $2+$ & $1+$ \\
1872 & 120 & $3 \pm$ & $1+$ \\
1774 & 110 & $2+$ & \pm \\
1771 & 410 & \pm & \pm \\
\hline
\end{tabular}

concentration did not appear to influence the results detectably.

Effect of indifferent RNA. In this group of experiments immune cells from the recipient popliteal lymph nodes were divided into two equal aliquots as before. One aliquot was incubated in RNA extracted from the lymph nodes of an indifferent rabbit; the other aliquot was incubated in sucrose medium alone. After incubation equal numbers of cells from each aliquot were injected intradermally into the donor rabbit as before. The results are summarized in Table VI. The transfer reaction was again inhibited in all but one experiment by incubation with RNA extracted from the lymph nodes of the indifferent rabbit, $\mathrm{p}<$ 0.001 .

Effect of liver RNA. In this final series of experiments immune cells from the recipient popliteal lymph nodes were again divided into two equal aliquots. One aliquot was incubated in RNA extracted from the liver of an indifferent rabbit. The other aliquot was simultaneously incubated in sucrose medium alone. After incubation equal numbers of cells from each aliquot were injected into opposite sides of the donor rabbit. As indicated in Table VII, incubation of the immune cells in rabbit liver RNA did not detectably inhibit the production of the transfer reaction by these cells in any instance.

\section{Discussion}

It is apparent that the phenol extraction procedure employed in the present studies yielded a preparation containing appreciable quantities of highly polymerized RNA as indicated by ultracentrifugal analysis and by the hyperchromatic effect upon alkali degradation and incubation with ribonuclease. The results of the present experiments also demonstrate that this RNA preparation can inhibit the production of the transfer reaction by sensitized lymph node cells from a homograft recipient, when these cells are injected intradermally into the homograft donor. RNA from the homograft donor and RNA extracted from the lymph nodes of an indifferent rabbit both appeared effective in this regard.

It is likely that RNA was responsible for the observed inhibition of the transfer reaction, since this effect was abolished by exposure of the RNA to small amounts of ribonuclease. It is also likely that the inhibition of the transfer reaction was not completely a nonspecific effect of incubation with RNA since, as might have been predicted from previous work from this laboratory $(6,7)$, incubation of immune recipient cells with RNA from one of the recipient's own lymph nodes did not inhibit the production of the transfer reaction by these cells. Similarly incubation with RNA extracted from rabbit liver did not inhibit the transfer reaction.

The mechanism through which lymphoid RNA inhibits the transfer reaction is not apparent from the present data. However, in the light of current concepts of the role of messenger RNA in protein synthesis (21-23), it is tempting to speculate that inhibition of the transfer reaction by lymph node RNA involves the incorporation of homologous messenger RNA by the inhibited cell. It is thus conceivable that the effectiveness of RNA from lymph nodes, other than those specifically stimulated by the tissues of the homograft

TABLE VII

Transfer reactions; immune cells plus liver $R N A$

\begin{tabular}{cccc}
\hline \hline $\begin{array}{c}\text { Rabbit } \\
\text { no. }\end{array}$ & $\begin{array}{c}\text { Concen- } \\
\text { tration } \\
\text { of RNA }\end{array}$ & $\begin{array}{c}\text { Right side } \\
\text { Cells }\end{array}$ & $\begin{array}{c}\text { Left side } \\
\text { Cells } \\
+ \text { RNA }\end{array}$ \\
\hline & $\mu g / m l$ & & \\
1858 & 950 & $5+$ & $5+$ \\
1874 & 950 & $4+$ & $4+$ \\
1870 & 680 & $1+$ & $1+$ \\
1862 & 680 & $4+$ & $4+$ \\
1346 & 350 & $2+$ & $2+$ \\
1338 & 400 & $3+$ & $3+$ \\
\hline
\end{tabular}


donor, might be on the basis of competitive inhibition. When incorporated by an immune cell, homologous, lymphoid, messenger RNA may compete for ribosomes with messenger RNA produced in the cell itself, which would normally direct the synthesis of antibody against donor tissue. The presence of the foreign, messenger RNA might thus inhibit the expression of immunity by the previously immunized cell. Such an explanation is, of course, purely speculative at present.

The conditions for incubating lymphoid cells with RNA in the current study were arrived at by borrowing from the experience of virologists $(1,2)$ who had previously determined that the penetration of free, viral RNA into mammalian cells was considerably enhanced by media of high ionic strength, that maximal incorporation of RNA was accomplished in a matter of minutes, and that the presence of protein in the incubation medium inhibited the biological activity of the RNA. Evidence that the lymphoid RNA prepared in the present study is incorporated by viable lymph node cells, during incubation under the conditions described, was afforded by the radioautographs of cells incubated with tritiumlabeled RNA. The possibility that the labeling might have resulted from adsorption of RNA onto the cell surface has not been entirely ruled out. However, the fact that washed cells were used to prepare the radioautographs and that labeling persisted after 48 hours' growth in tissue culture argues strongly against adsorption as an explanation for these results. The observation that cell labeling was not depressed by a large excess of unlabeled uridine and was inhibited by a large excess of unlabeled RNA would indicate that the tritium label had entered the cells as part of an RNA molecule. No evidence was obtained in these experiments as to whether or not there was selective labeling of one or another of several RNA fractions present in the crude RNA preparation, or whether there was selective incorporation of one or more of these fractions by the cells during incubation. Recent work by Fishman, Hammerstrom, and Bond (24), however, suggests that a fraction of relatively low molecular weight is incorporated preferentially.

The use of rabbits of a single strain in these experiments may be criticized. Dvorak and
Waksman (10) have pointed out that, in their experience with the transfer reaction, white New Zealand rabbits yielded inconsistent results when immunized against one another by skin grafts. Previous work in this laboratory has also indicated that a single skin graft frequently provided insufficient stimulus to the regional lymph nodes to permit consistently positive transfer reactions in rabbits of this strain. However, a skin graft coupled with an injection of lymphoid cells did provide sufficiently effective sensitization to allow quite consistent production of strongly positive transfer reactions by regional lymph node cells $(6,7)$ as confirmed by the results reported here. Therefore, it did not appear that there was any significant disadvantage in using rabbits of the same strain for the present series of experiments, particularly since skin grafts exchanged at random between rabbits of this strain have been rejected consistently in $7.4 \pm 1.2$ (SD) days (25), demonstrating considerable individual disparity with regard to transplantation antigens.

Criticism may also be leveled at the use of the transfer reaction as a test for transplantation immunity. Although the association of the transfer reaction with the state of transplantation immunity has been adequately demonstrated by Brent and associates (9), by Dvorak and Waksman (10), and by the present results, there is nevertheless no direct evidence that the inflammatory response produced by the putatively immune cells is the same response which results, for example, in the rejection of a skin homograft. In addition, there is no convincing evidence that the pathology of the transfer reaction is sufficiently unique to distinguish it from other less specific inflammatory reactions. However, the relative but not absolute specificity of the reaction for the homograft donor, as demonstrated in previous work from this laboratory (7), adds force to the argument that this reaction is an immune response. Since the immunity was originally produced by the transplantation of skin and lymphoid cells, it does not appear unreasonable to term it transplantation immunity.

The question arises as to how many immune recipient cells were necessarily altered in each experiment to produce the observed effect. The present radioautographic studies indicate that it is not unlikely that $20 \%$ of the cells would in- 
corporate the homologous RNA during incubation and thus, potentially, could be inhibited from producing the transfer reaction. Previous work in this laboratory has shown that at least 4 to 10 million cells are necessary to produce transfer reactions consistently $(6,7)$ and that smaller numbers of cells frequently fail to produce a significant response. Therefore it appears reasonable to assume that the difference between the critical number of immune cells necessary for a detectable transfer reaction and the number incapable of eliciting such a response is rather small, perhaps 2 or 3 million cells. Postulated alteration of approximately $20 \%$ of the incubated cells then should be sufficient to inhibit the production of the transfer reaction.

Whether or not the present results have any relevance to the prevention of homograft rejection in vivo remains unsettled. In this regard mention should be made of the work of Ashley and associates (26), Jolley, Hinshaw, and Peterson (27), and Axelrod and Lowe (28). These groups of investigators have presented evidence which suggests that foreign (homologous) lymphoid RNA administered systemically prolongs significantly the survival of skin homografts in at least two mammalian species. The mechanism of action of the foreign RNA in producing the results observed by these investigators is particularly difficult to decipher, since the plasma and tissue fluids of most mammals contain sufficient ribonuclease to destroy, theoretically at least, large quantities of free RNA in a matter of seconds (29). The attempted use of homologous lymphoid RNA to inhibit the rejection of homografts in vivo raises the question of whether the effect of the homologous RNA is transient or will persist in the descendents of the cells which have incorporated it. A transient effect would be much more likely because of the considerable body of data $(21,23,30)$ which indicates that messenger RNA in bacteria is unstable and is turned over rapidly. More recent observations, however, suggest that this may not be the case for messenger RNA in certain types of mammalian cells (31). Of particular relevance is the work of Mitchell and Nossal (32), who have presented evidence that the messenger RNA of antibody-forming cells may be turned over extremely slowly if at all. Further evidence that the alterations in intra- cellular metabolism produced by some forms of RNA may be more than transitory has been presented by Niu $(33,34)$, who has shown that RNA-induced enzyme synthesis in cultured ascites tumor cells remains stable for more than 20 weeks.

Presumably a full scale attempt to inhibit transplantation immunity by homologous lymphoid RNA in vivo, in a manner similar to that employed in vitro in the present experiments, would require infusion of large quantities of homologous lymphoid RNA coupled with the administration of a potent ribonuclease inhibitor. Studies to test this possibility are currently in progress.

\section{Summary}

1) The extraction of RNA from rabbit lymphoid tissue is described.

2) Chemical, spectrophotometric, and ultracentrifugal analyses of the RNA preparation are presented.

3) Evidence for the incorporation of RNA from this preparation by lymph node cells during incubation in vitro was obtained by radioautography of cells incubated with tritium-labeled RNA.

4) With the transfer reaction as an assay for transplantation immunity in rabbits, it was determined that immune lymph node cells from a homograft recipient were inhibited from producing the transfer reaction by incubation with RNA extracted from the lymph nodes of the homograft donor or from the lymph nodes of an indifferent rabbit.

5) The ability of donor lymph node RNA to inhibit the transfer reaction was abolished by treatment of the RNA with small amounts of ribonuclease.

6) RNA extracted from the lymph nodes of the homograft recipient and RNA extracted from rabbit liver did not inhibit the production of the transfer reaction by immune recipient lymph node cells.

\section{Acknowledgments}

The author is indebted to Dr. Alfred Richard for performing the ultracentrifugal analyses and to $\mathrm{Mr}$. Farley Moxley and Mrs. Florene Booth for expert technical assistance. 


\section{References}

1. Alexander, H. E., G. Koch, I. M. Mountain, and O. Van Damme. Infectivity of ribonucleic acid from poliovirus in human cell monolayers. J. exp. Med. 1958, 108, 493.

2. Ellem, K. A. O., and J. S. Colter. The interaction of infectious ribonucleic acid with a mammalian cell line. I. Relationship between the osmotic pressure of the medium and the production of infectious centers. Virology 1960, 11, 434

3. DeCarvalho, S., and H. J. Rand. Comparative effects of liver and tumor ribonucleic acids on the normal liver and Novikoff hepatoma cells of the rat. Nature (Lond.) 1961, 189, 815.

4. Niu, M. C., C. C. Cordova, and L. C. Niu. Ribonucleic acid-induced changes in mammalian cells Proc. nat. Acad. Sci. (Wash.) 1961, 47, 1689.

5. Amos, H., and K. E. Kearns. Synthesis of "bacterial" protein by cultured chick cells. Nature (Lond.) 1962, 195, 806.

6. Mannick, J. A., and R. H. Egdahl. Ribonucleic acid in "transformation" of lymphoid cells. Science 1962, 137, 976.

7. Mannick, J. A., and R. H. Egdahl. Transformation of nonimmune lymph node cells to state of transplantation immunity by RNA. A preliminary report. Ann. Surg. 1962, 156, 356.

8. Fishman, M., and F. L. Adler. Antibody formation initiated in vitro. II. Antibody synthesis in $\mathrm{x}$-irradiated recipients of diffusion chambers containing nucleic acid derived from macrophages incubated with antigen. J. exp. Med. 1963, 117, 595.

9. Brent, L., J. B. Brown, and P. B. Medawar. Skin transplantation immunity in relation to hypersensitivity. Lancet 1958, 2, 561.

10. Dvorak, H. F., and B. H. Waksman. Primary immunization of lymph node cells in Millipore chambers by exposure to homograft antigen. J. exp. Med. 1962, 116, 1.

11. Jankovic, B. D., and H. F. Dvorak. Enzymatic inactivation of immunologically competent lymph node cells in the "transfer reaction." J. Immunol. 1962, 89, 571.

12. Colter, J. S., and R. A. Brown. Preparation of nucleic acids from Ehrlich ascites tumor cells. Science 1956, 124, 1077.

13. Gierer, A., and G. Schramm. Infectivity of ribonucleic acid from tobacco mosaic virus. Nature (Lond.) 1956, 177, 702.

14. Dische, Z. Color reactions of nucleic acid components in The Nucleic Acids, E. Chargaff, and J. N. Davidson, Eds. New York, Academic Press, 1955, vol. 1, p. 287.

15. Zamenhof, S. Preparation and assay of deoxyribonucleic acid from animal tissue in Methods in Enzymology, S. P. Colowick, and N. O. Kaplan, Eds. New York, Academic Press, 1957, vol. 3, p. 702.
16. Ma, T. S., and G. Zuazaga. Micro-Kjeldahl determination of nitrogen. A new indicator and an improved rapid method. Industr. eng. Chem. analyt. Ed. 1942, 14, 280.

17. Hawk, P. B., B. L. Oser, and W. H. Summerson. Practical Physiological Chemistry, 13th ed. New York, McGraw-Hill, 1954, p. 635.

18. Hotchkiss, R. D. Characterization of nucleic acids by spectrophotometry in Methods in Enzymology, S. P. Colowick, and N. O. Kaplan, Eds. New York, Academic Press, 1957, vol. 3, p. 710.

19. Mejbaum, W. Utber die Bestimmung Kleiner Pentosemengen insbesondere in Derivaten der Adenylsäure. Hoppe-Seylers Z. physiol. Chem. 1939, 258, 117.

20. Snedecor, G. W. Statistical Methods Applied to Experiments in Agriculture and Biology. Ames, Iowa, Iowa State University Press, 1956, p. 219.

21. Jacob, F., and J. Monod. Genetic regulatory mechanisms in synthesis of proteins. J. molec. Biol. 1961, 3, 318 .

22. Nirenberg, M. W., and J. H. Mathaei. The dependence of cell-free protein synthesis in $E$. coli upon naturally occurring or synthetic polyribonucleotides. Proc. nat. Acad. Sci. (Wash.) 1961, 47, 1588.

23. Spiegelman, S. Information transfer from the genome. Fed. Proc. 1963, 22, 36.

24. Fishman, M., R. A. Hammerstrom, and V. P. Bond. In vitro transfer of macrophage RNA to lymph node cells. Nature (Lond.) 1963, 198, 549.

25. Mannick, J. A., H. R. Cress, H. M. Lee, and R. H. Egdahl. Transplantation antigenicity of lymphoid cells grown in vitro. Amer. J. Surg. 1963, 105, 167.

26. Ashley, F. L., E. G. McNall, N. R. Dutt, E. N. Garcia, and R. F. Sloan. The effects of nucleic acids on homograft tolerance. Ann. N. Y. Acad. Sci. $1960,87,429$.

27. Jolley, W. B., D. B. Hinshaw, and M. Peterson. Effect of ribonucleic acid on homograft survival. Surg. Forum 1961, 12, 99.

28. Axelrod, A. E., and M. Lowe. Effect of ribonucleic acid extracts upon viability of skin homografts in the rat. Proc. Soc. exp. Biol. (N. Y.) 1961, $108,549$.

29. Herriott, R. M. Infectious nucleic acids, a new dimension in virology. Science 1961, 134, 256.

30. Volkin, E. Synthesis and function of the DNA-like RNA. Fed. Proc. 1962, 21, 112.

31. Nathans, D., G. Von Ehrenstein, R. Monro, and F. Lipmann. Protein synthesis from aminoacyl-soluble ribonucleic acid. Fed. Proc. 1962, 21, 127.

32. Mitchell, J., and G. J. V. Nossal. Ribonucleic acid metabolism in the plasma cell sequence. Nature (Lond.) 1963, 197, 1121.

33. Niu, M. C. The mode of action of ribonucleic acid. Develop. Biol. 1963, 7, 379.

34. Niu, M. C. The stability of the RNA-induced cellular changes. Fed. Proc. 1963, 22, 354. 